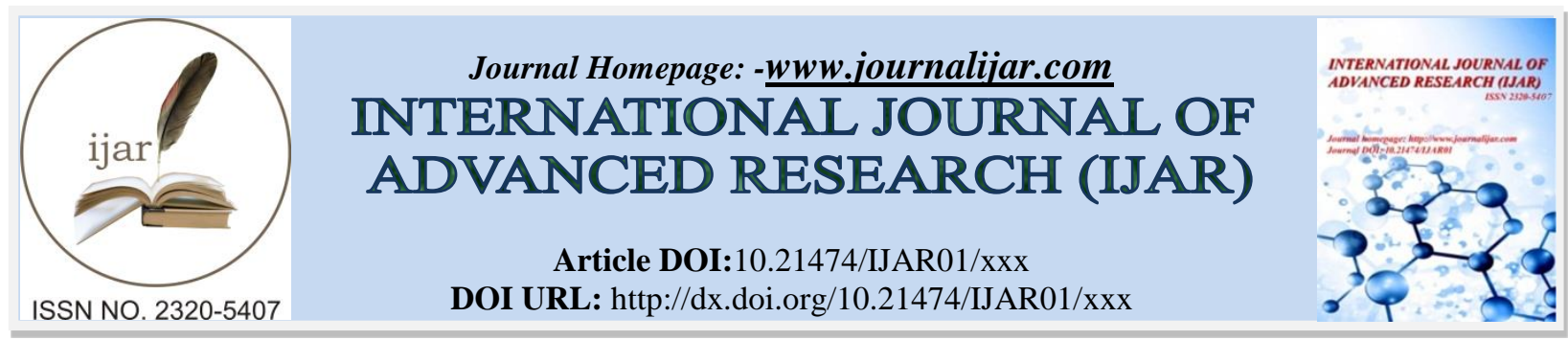

RESEARCH ARTICLE

\title{
AGE AS AN INDEPENDENT PROGNOSTIC FACTOR IN BREAST CANCER.
}

\author{
H. Fayed ${ }^{1}$, A. T. Awed ${ }^{1}$ and Azza Darweesh ${ }^{2}$. \\ 1. Department of surgery, Alexandria faculty of medicine. \\ 2. Department of clinical oncology, Alexandria faculty of medicine.
}

\section{Manuscript Info}

Manuscript History

Received: $x x x x x x x x x x x x x x x x$

Final Accepted: $x x x x x x x x x x x x$

Published: $\operatorname{xxxxxxxxxxxxxxx}$

Key words:-

breast cancer, molecular biology, survival, young age.

\begin{abstract}
Introduction: Breast cancer is the commonest cancer among females in both developed and developing countries [1]. In the field of breast cancer, in most of the articles, young woman is defined to be below the age of 35 or the age of 40 [2]. The results of the National PopulationBased Cancer Registry Program in Egypt, showed that, among females, the proportion of breast cancer was $32 \%$ of all female cancers [3]. In study applied in Gharbia over 10 years (1999-2008), the result was that the majority of breast cancer cases during the study period were diagnosed among women aged $40-49$ years $(31.8 \%)$ and among women aged 50-59 years (29.8\%) [4] one decade younger than the corresponding age in western countries.

Patients and methods: This was a retrospective study in which the records of patients presenting with breast carcinoma who were admitted to the unit of Surgical Oncology and to the Clinical Oncology and Nuclear Medicine department, Alexandria Main University Hospital from January 2005 to December 2013 were collected. These patients were followed for 5 years after completion of their treatment.

Results: There was higher incidence of hormone positive tumors in older patients with a significant difference statistically ( $p 0.001$ for ER receptors and $p 0.010$ for PR receptors). there is a significant reduction in the disease-free survival $(p<0.001)$ and overall survival $(p<0.001)$ in patients who developed breast cancer before 40 years.

Conclusion: Hormone-positive tumors are more common in patients older than 40 years which may indicate a better prognosis in this age group. Younger age at diagnosis of breast cancer is an adverse prognostic factor for relapse of the disease even when effective adjuvant therapy is given. This based on disease free survival and overall survival are worse in young age group.
\end{abstract}

Copy Right, IJAR, 2019,. All rights reserved.

\section{Introduction:-}

Breast cancer is the commonest cancer among females in both developed and developing countries [1]. In the field of breast cancer, in most of the articles, young woman is defined to be below the age of 35 or the age of 40 [2]. The results of the National Population-Based Cancer Registry Program in Egypt, showed that, among females, the proportion of breast cancer was $32 \%$ of all female cancers [3]. In study applied in Gharbia over 10 years (1999- 
2008), the result was that the majority of breast cancer cases during the study period were diagnosed among women aged $40-49$ years $(31.8 \%)$ and among women aged 50-59 years $(29.8 \%)$ [4], one decade younger than the corresponding age in western countries. Breast cancer in Egypt has been reported to be biologically more aggressive disease than that in Western countries with predominance of premenopausal patients with late presentation in advanced stages [5,6]. The incidence of breast cancer among young females in Africa and Middle East reaches up to $20 \%$ of cases. The aetiology of this high incidence may be attributed to genetic or environmental factors [7]. Young patients diagnosed with breast cancer usually have a worse prognosis than older patients [8]. Young women diagnosed with breast cancer experience the same problems experienced by their older counterparts like abdominal pain, hair loss and bone aches in addition to the problems of infertility, early menopause, changed body image and sexuality [9]. Age is considered as an independent prognostic factor. Breast cancer occurring young women tends to have an aggressive behaviour such as HER2 over-expression and triple negative subtypes and is more likely to be diagnosed in a late stage. This may explain the poor outcome of younger patients as regarding the locoregional recurrence and the overall survival $[10,11]$. Breast conserving therapy in women younger than 35 years is associated with higher risk of local recurrence than older patients [12].

\section{Patients and methods:}

This was a retrospective study in which the records of patients presenting with breast carcinoma who were admitted to the unit of Surgical Oncology and to the Clinical Oncology and Nuclear Medicine department, Alexandria Main University Hospital from January 2005 to December 2013 were collected. All available records and blocks for these patients were retrieved. 5 years follow up period for these patients after completion of treatment.

\section{In this study, we divided all patients in to two groups:}

1. Group I: patients presenting with Breast carcinoma at age $\leq 40$ years.

2. Group II: patients presenting with Breast carcinoma at age $>40$ years.

Exclusion criteria for this study included:

1. Male breast cancer

2. Patients with pathology rather than carcinoma

3. Patients without data about pathological assessment and patients without follow-up records.

Data were fed to the computer and analyzed using IBM SPSS software package version 20.0. (Armonk, NY: IBM Corp). The Kolmogorov- Smirnov, Shapiro and D'agstino tests were used to verify the normality of distribution of variables, Comparisons between groups for categorical variables were assessed using Chi-square test (Fisher or Monte Carlo). Mann Whitney test was used to compare between two groups for abnormally distributed quantitative variables. Kaplan-Meier Survival curve was used. Significance of the obtained results was judged at the $5 \%$ level.

\section{Results:-}

The study was done on 3820 cases diagnosed with breast cancer in the period between January 2005 to December 2013 with follow up period of 5 years.

Some of the reports were deficient in some parts.

Patients younger than 40 years at the time of diagnosis represents $15.6 \%$ of all cases (fig. 1)

There was a higher incidence of cribriform insitu carcinoma in younger patients. More breast conserving surgeries and oncoplastic procedure were done for young patients. Mastectomy was done in most of the cases. (table 1)

Table 2 shows the different parameters studied and comparing both age groups in relation to these parameters. There was higher incidence of hormone positive tumors in older patients with a significant

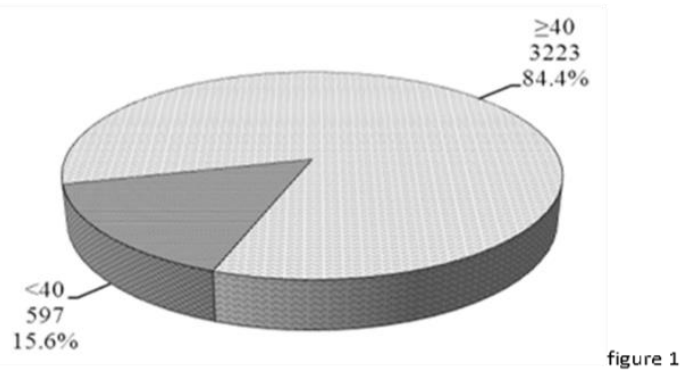

Figure 1: Age distribution among the studied group 
difference statistically ( $p 0.001$ for ER receptors and $p 0.010$ for PR receptors)

Table 3,4 and figure 2 show that there is a significant reduction in the disease-free survival $(p<0.001)$ and overall survival $(p<0.001)$ in patients who developed breast cancer at age younger than 40 years.

By the end of the study (5 years),31 patients in the young group died from the disease and 16 patients in the old group died from the disease with statistical significance $(p<0.001)$

Table 1:- Comparison between the two age groups according to different parameters

\begin{tabular}{|c|c|c|c|c|}
\hline & \multicolumn{2}{|l|}{ Age (years) } & \multirow[t]{2}{*}{ Test of sig. } & \multirow[t]{2}{*}{$\mathbf{p}$} \\
\hline & $<40$ & $\geq \mathbf{4 0}$ & & \\
\hline Multiplicity & $(n=122)$ & $(n=539)$ & & \\
\hline Single & $109(89.3 \%)$ & 491(91.1\%) & \multirow[t]{3}{*}{$\chi^{2}=0.398$} & \multirow[t]{3}{*}{0.820} \\
\hline Multifocal & $9(7.4 \%)$ & $32(5.9 \%)$ & & \\
\hline Multicentric & $4(3.3 \%)$ & $16(3 \%)$ & & \\
\hline Neoadjuvant Type & $(n=389)$ & $(n=1877)$ & & \\
\hline No & $367(94.3 \%)$ & $1757(93.6 \%)$ & \multirow{2}{*}{$\chi^{2}=0.298$} & \multirow[b]{2}{*}{0.585} \\
\hline Yes & $22(5.7 \%)$ & $120(6.4 \%)$ & & \\
\hline Response to Neoadjuvant & $(\mathbf{n}=10)$ & $(\mathbf{n}=\mathbf{5 0})$ & & \\
\hline Partial response & $6(60 \%)$ & $27(54 \%)$ & \multirow{3}{*}{$\chi^{2}=1.214$} & \multirow{3}{*}{0.622} \\
\hline Poor response & $4(40 \%)$ & $16(32 \%)$ & & \\
\hline Complete path response & $0(0 \%)$ & $7(14 \%)$ & & \\
\hline Type of surgery & $(n=490)$ & $(n=2421)$ & & \\
\hline No & $9(1.8 \%)$ & $21(0.9 \%)$ & \multirow[t]{6}{*}{$\chi^{2}=15.696$} & \multirow[t]{6}{*}{$0.004^{*}$} \\
\hline BCT & $41(8.4 \%)$ & $114(4.7 \%)$ & & \\
\hline Oncoplastic & $0(0 \%)$ & $1(0.04 \%)$ & & \\
\hline Mastectomy & $438(89.4 \%)$ & $2278(94.1 \%)$ & & \\
\hline Mastectomy \& Recon & $1(0.2 \%)$ & $2(0.1 \%)$ & & \\
\hline Qudrantectomy & $1(0.2 \%)$ & $5(0.2)$ & & \\
\hline T size & $(\mathbf{n}=297)$ & $(n=1581)$ & & \\
\hline Median (Min. - Max.) & $4(0.1-18)$ & $3.50(0-17)$ & $\mathrm{U}=221920.5$ & 0.130 \\
\hline Pathology Types & $(n=438)$ & $(\mathbf{n}=2192)$ & & \\
\hline IDC & $420(95.9 \%)$ & $2051(93.6 \%)$ & $\chi^{2}=3.468$ & 0.063 \\
\hline ILC & $3(0.7 \%)$ & $56(2.6 \%)$ & $\chi^{2}=5.820^{*}$ & $0.016^{*}$ \\
\hline DCI & $2(0.5 \%)$ & $9(0.4 \%)$ & $\chi^{2}=0.019$ & 1.000 \\
\hline Mixed & $5(1.1 \%)$ & $51(2.3 \%)$ & $\chi^{2}=2.460$ & 0.117 \\
\hline Medullary & $5(1.1 \%)$ & $12(0.5 \%)$ & $\chi^{2}=2.006$ & 0.183 \\
\hline Paget dis with IDC & $0(0 \%)$ & $5(0.2 \%)$ & $\chi^{2}=1.001$ & 0.598 \\
\hline Mucinous & $1(0.2 \%)$ & $6(0.3 \%)$ & $\chi^{2}=0.028$ & 1.000 \\
\hline LCIS & $0(0 \%)$ & $1(0.05 \%)$ & $\chi^{2}=0.200$ & 1.000 \\
\hline Cribriform & $2(0.5 \%)$ & $0(0 \%)$ & $\chi^{2}=10.017^{*}$ & $0.028^{*}$ \\
\hline Paget disease with DCIS & $0(0 \%)$ & $1(0.05 \%)$ & $\chi^{2}=0.200$ & 1.000 \\
\hline Tumor grade & $(\mathbf{n}=317)$ & $(n=1528)$ & & \\
\hline 1 & $15(4.8 \%)$ & $59(3.9 \%)$ & & \\
\hline 2 & $255(80.4 \%)$ & $1281(83.8 \%)$ & $\chi 2=2.349$ & 0.672 \\
\hline 3 & $47(14.8 \%)$ & $188(12.3 \%)$ & & \\
\hline LV invasion & $(\mathbf{n}=\mathbf{1 8 0})$ & $(n=841)$ & & \\
\hline Yes & $104(57.8 \%)$ & $469(55.8 \%)$ & $\chi^{2}=0.243$ & 0.622 \\
\hline No & $76(42.2 \%)$ & $372(44.2 \%)$ & & \\
\hline
\end{tabular}

$\chi^{2}, p: \chi^{2}$ and $p$ values for Chi square test for comparing between the two groups $U$, $p: U$ and $p$ values for Mann Whitney test for comparing between the two groups: Statistically significant at $\mathrm{p} \leq 0.05$ 
Table 2:-Comparison between the two age groups according to different parameters

\begin{tabular}{|c|c|c|c|c|}
\hline & \multicolumn{2}{|l|}{ Age (years) } & \multirow[t]{2}{*}{ Test of sig. } & \multirow[t]{2}{*}{$\mathbf{p}$} \\
\hline & $<40$ & $\geq 40$ & & \\
\hline Pathological T & $(n=298)$ & $(n=1503)$ & & \\
\hline 0 & $0(0 \%)$ & $1(0.1 \%)$ & \multirow{5}{*}{$\chi^{2}=3.679$} & \multirow[t]{5}{*}{0.469} \\
\hline 1 & $44(14.8 \%)$ & $281(18.7 \%)$ & & \\
\hline 2 & $178(59.7 \%)$ & $870(57.9 \%)$ & & \\
\hline 3 & $62(20.8 \%)$ & $275(18.3 \%)$ & & \\
\hline 4 & $14(4.7 \%)$ & $76(5.1 \%)$ & & \\
\hline Median (Min. - Max.) & $2(1-4)$ & $2(0-4)$ & $\mathrm{U}=213583.0$ & 0.155 \\
\hline Pathological N & $(n=337)$ & $(n=1577)$ & & \\
\hline 0 & $91(27 \%)$ & $475(30.1 \%)$ & \multirow[t]{4}{*}{$\chi^{2}=3.241$} & \multirow[t]{4}{*}{0.356} \\
\hline 1 & $90(26.7 \%)$ & $429(27.2 \%)$ & & \\
\hline 2 & $98(29.1 \%)$ & $456(28.9 \%)$ & & \\
\hline 3 & $58(17.2 \%)$ & $217(13.8 \%)$ & & \\
\hline Median (Min. - Max.) & $1(0-3)$ & $1(0-3)$ & $\mathrm{U}=251672.5$ & 0.113 \\
\hline Stage & $(n=296)$ & $(n=1451)$ & & \\
\hline 0 & $0(0 \%)$ & $1(0.1 \%)$ & \multirow{5}{*}{$\chi^{2}=4.502$} & \multirow[t]{5}{*}{0.356} \\
\hline 1 & $18(6.1 \%)$ & $103(7.1 \%)$ & & \\
\hline 2 & $116(39.2 \%)$ & $638(44.0 \%)$ & & \\
\hline 3 & $158(53.4 \%)$ & $697(48.0 \%)$ & & \\
\hline 4 & $4(1.4 \%)$ & $12(0.8 \%)$ & & \\
\hline Stage Level & $(n=296)$ & $(n=1450)$ & & \\
\hline Early stage & $122(41.2 \%)$ & $673(46.4 \%)$ & \multirow[t]{3}{*}{$\chi^{2}=3.436$} & \multirow[t]{3}{*}{0.179} \\
\hline Locally advanced & $170(57.4 \%)$ & $766(52.8 \%)$ & & \\
\hline Metastatic & $4(1.4 \%)$ & $11(0.8 \%)$ & & \\
\hline ER score & $(n=309)$ & $(n=1351)$ & & \\
\hline Negative & $70(22.7 \%)$ & $200(14.8 \%)$ & \multirow{2}{*}{$\chi^{2}=11.378^{*}$} & \multirow[t]{2}{*}{$0.001^{*}$} \\
\hline Positive & $239(77.3 \%)$ & $1151(85.2 \%)$ & & \\
\hline PR test & $(n=309)$ & $(n=1411)$ & & \\
\hline Negative & $79(25.6 \%)$ & $269(19.1 \%)$ & \multirow[t]{2}{*}{$\chi^{2}=6.640^{*}$} & \multirow[t]{2}{*}{$0.010^{*}$} \\
\hline Positive & $230(74.4 \%)$ & $1142(80.9 \%)$ & & \\
\hline HER2 & $(n=90)$ & $(n=373)$ & & \\
\hline Positive & $18(20 \%)$ & $59(15.8 \%)$ & \multirow[t]{2}{*}{$\chi^{2}=0.151$} & \multirow[t]{2}{*}{0.697} \\
\hline Negative & $72(80 \%)$ & $314(84.2 \%)$ & & \\
\hline KI & $(n=48)$ & $(n=171)$ & & \\
\hline Low & $26(54.2 \%)$ & $100(58.5 \%)$ & \multirow[t]{2}{*}{$\chi^{2}=0.285$} & \multirow[t]{2}{*}{0.593} \\
\hline High & $22(45.8 \%)$ & $71(41.5 \%)$ & & \\
\hline
\end{tabular}

$\chi^{2}, \mathrm{p}: \chi^{2}$ and $\mathrm{p}$ values for Chi square test for comparing between the two groups

$\mathrm{U}, \mathrm{p}$ : $\mathrm{U}$ and $\mathrm{p}$ values for Mann Whitney test for comparing between the two groups

*: Statistically significant at $\mathrm{p} \leq 0.05$ 


\section{Discussion:-}

Breast cancer in females before the age of 40 years is uncommon and reaches nearly $7 \%$ of all cases at diagnosis in United States. According to many epidemiological studies in the last twenty years, this group of patients has raised special interest for being associated with poorer prognosis when compared to cases diagnosed over the age of 40 . The majority of these studies were done in Europe

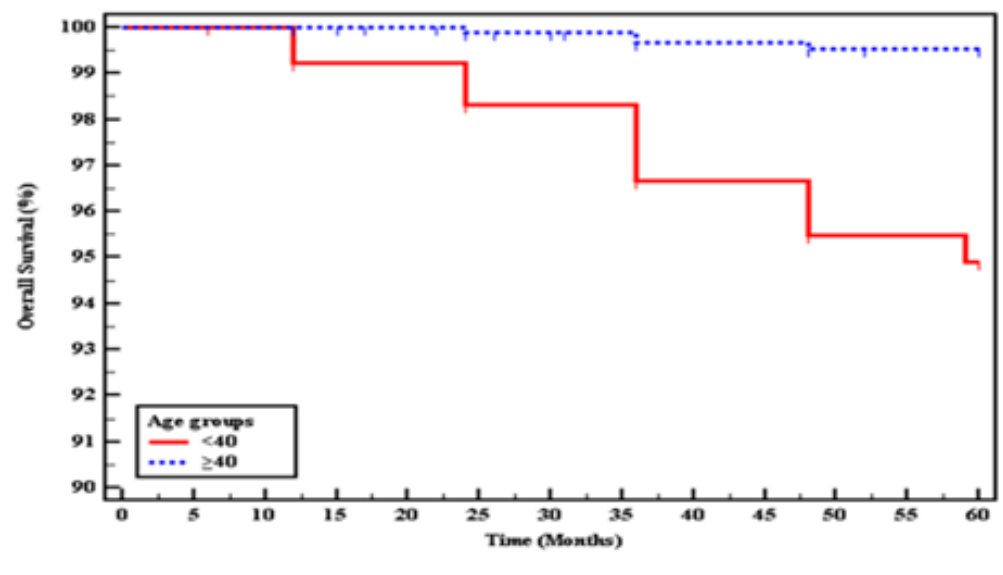
and United States $[13,14]$.

Since breast cancer is considered a potentially curable disease, a more aggressive approach may be needed if it is confirmed that young patients with breast cancer have increased incidence of relapse and low survival [15].

In the United States, a large retrospective cohort study of 243,012 breast cancer patients diagnosed between 1988 and 2003, showed that only $6.4 \%$ were younger than 40 years old [16]. While in our study, we found that patients diagnosed with breast cancer account for $15.6 \%$ of cases. This disparity is attributed to differences in population structure with more young population in Egypt; median age of females' population in Egypt is 24 years at 2016 while in USA median age is 38 years at 2016. Also, Egyptian female life expectancy, while increasing greatly in the last 50 years from approximately 49 years in 1960 to 74 years for 2016, is still currently lower than the USA 2016 estimate of 82 years.

In the current study, no significant association with age groups as regard the presence of lymphovascular invasion, although there was a higher incidence of presence of lymphovascular invasion in the young group, a finding similar to that reported in many published series [17]. On contrast Song et al [18] showed LVI was significantly associated with young patients aged $\leq 40$ years, also Cancello et al [19] concluded that there were higher percentages of tumors with LVI in young patients.

In our study; there was no statistically significant difference in the distribution of TNM stage between two age groups. These results were consistent with many studies [20, 21]. In contrast, several studies concluded that the percentage of patients diagnosed with more advanced stages was higher in the young patients than the older patients $[22,23]$. While LIN et al [15] concluded that younger patients ( $<50$ years) were significantly associated with higher frequencies of stage I than older patients ( $\geq 50$ years).

In the current study, there were more ER and PR negative cases in the younger age group than in the older age group with statistical significance. This matches with the results of many studies that showed the same results $[19,22]$.

In the current work, there was no significant difference in HER-2 positivity between 2 age groups, which is consistent with other published works analysing series of young patients [24, 25]. While many studies concluded that HER2 positivity is more frequent in young patients which inversely affect the prognosis of young breast cancer patients [19, 22 and 26].

In our study, the 5 years disease free survival was less in young patients with higher relapse rate with statistical significance. Also, the overall survival was less in the young age group. This is not explained by the primary size of the tumor or the lymph node status as they were more or less the same in both groups with no statistical significance. 
These results are consistent with results from many published data which reported that Being 40 or younger is an independent risk factor for relapse in operable breast cancer patients [17, 22 and 27].

Table 3:- Comparison between the two age groups according to different parameters

\begin{tabular}{|c|c|c|c|c|}
\hline & \multicolumn{2}{|l|}{ Age (years) } & \multirow[t]{2}{*}{ Test of sig. } & \multirow{2}{*}{$\mathbf{p}$} \\
\hline & $<40$ & $\geq 40$ & & \\
\hline Luminal subtypes & $(n=58)$ & $(n=205)$ & & \\
\hline A & $14(24.1 \%)$ & $71(34.6 \%)$ & \multirow[t]{5}{*}{$\chi^{2}=4.590$} & \multirow[t]{5}{*}{0.332} \\
\hline B Her2 -ve & $13(22.4 \%)$ & $49(23.9 \%)$ & & \\
\hline B Her2 +ve & $13(22.4 \%)$ & $44(21.5 \%)$ & & \\
\hline Her2 Enriched & $5(8.6 \%)$ & $15(7.3 \%)$ & & \\
\hline Triple -ve & $13(22.4 \%)$ & $26(12.7 \%)$ & & \\
\hline Hormonal status tumor & $(\mathbf{n}=\mathbf{3 2 6})$ & $(n=1487)$ & & \\
\hline Negative & $54(16.6 \%)$ & $143(9.6 \%)$ & \multirow[t]{2}{*}{$\chi^{2}=13.326^{*}$} & \multirow[t]{2}{*}{$<0.001^{*}$} \\
\hline Positive & $272(83.4 \%)$ & $1344(90.4 \%)$ & & \\
\hline Disease free survival event & $(\mathbf{n}=281)$ & $(\mathbf{n}=1231)$ & & \\
\hline Free & $156(55.5 \%)$ & $851(69.1 \%)$ & \multirow[t]{2}{*}{$\chi^{2}=19.064^{*}$} & \multirow[t]{2}{*}{$<0.001^{*}$} \\
\hline Mets & $125(44.5 \%)$ & $380(30.9 \%)$ & & \\
\hline $5 \mathrm{yr}$ dis free months & $(n=261)$ & $(n=1147)$ & & \\
\hline Median (Min. - Max.) & $48(0-60)$ & $48(0-60)$ & $\mathrm{U}=133373.5^{*}$ & $0.004^{*}$ \\
\hline Overall survival event & $(n=284)$ & $(\mathbf{n}=1234)$ & & \\
\hline Alive & $274(96.5 \%)$ & $1230(99.7 \%)$ & \multirow[t]{2}{*}{$\chi^{2}=25.823^{*}$} & \multirow[t]{2}{*}{$<0.001^{*}$} \\
\hline Died & $10(3.5 \%)$ & $4(0.3 \%)$ & & \\
\hline 5yr OS (months) & $(n=259)$ & $(n=1141)$ & & \\
\hline Median (Min. - Max.) & $60(6-60)$ & $60(12-60)$ & $\mathrm{U}=141503.5$ & 0.211 \\
\hline
\end{tabular}

$\chi^{2}, \mathrm{p}: \chi^{2}$ and $\mathrm{p}$ values for Chi square test for comparing between the two groups

$\mathrm{U}, \mathrm{p}$ : $\mathrm{U}$ and $\mathrm{p}$ values for Mann Whitney test for comparing between the two groups

*: Statistically significant at $\mathrm{p} \leq 0.05$

Table 4:- Kaplan-Meier survival curve for overall survival

\begin{tabular}{|l|l|l|l|l|}
\hline Age groups & Mean (months) & $\begin{array}{l}\text { \% End of the } \\
\text { study }\end{array}$ & \multicolumn{2}{|c|}{ Log rank } \\
\cline { 3 - 5 } & & 94.9 & $\square^{\square}$ & p \\
\hline$<\mathbf{4 0}$ & 58.8 & 99.5 & $27.672^{*}$ & $<0.001^{*}$ \\
\hline$\geq \mathbf{4 0}$ & 59.9 & & \\
\hline
\end{tabular}

Conclusion:-

1. Hormone-positive tumors are more common in patients older than 40 years which may indicate a better prognosis in this age group.

2. Younger age at diagnosis of breast cancer is an adverse prognostic factor for relapse of the disease even when effective adjuvant therapy is given. This based on disease free survival and overall survival are worse in young age group.

\section{References:-}

1. Monica M Rivera-Franco and Eucario Leon-Rodriguez. Delays in Breast Cancer Detection and Treatment in Developing Countries. Breast Cancer: Basic and Clinical Research Volume 12: 1-5.

2. Courtney A Gabriel and Susan M Domchek. Breast cancer in young women. Breast Cancer Research 2010, 12:212.

3. Ibrahim AM, Khaled HM, Mikhail NN, Baraka H, Kamer H.Cancer Incidence in Egypt: Results of the National Population-Based Cancer Registry Program. J Cancer Epidemiol 2014;2014:1-18.

4. Hirko KA, Soliman AS, Hablas A, Seifeldin IA, Ramadan M, Banerjee M, et al. Trends in breast cancer incidence rates by age and stage at diagnosis in Gharbiah, Egypt, over 10 Years (1999-2008). J Cancer Epidemiol 2013;2013:916394.

5. Omar S, Khaled H, Gaafar R, Zekry AR, Eissa S, el-Khatib O. Breast cancer in Egypt: a review of disease presentation and detection strategies. East Mediterr Health J 2003;9(3):448-63. 
6. Schlichting JA, Soliman AS, Schairer C, Harford JB, Hablas A, Ramadan M, et al. Breast Cancer by Age at Diagnosis in the Gharbiah, Egypt, Population-Based Registry Compared to the United States Surveillance, Epidemiology, and End Results Program, 2004-2008. BioMed Research International 2015;2015:9.

7. Hatem A Azim and Ann H Partridge. Biology of breast cancer in young women. Breast Cancer Research 2014, $16: 427$.

8. M. batori, M. Ruggieri, E. Chtelou, A. Straiero, G. Mariotta, L. Palombi, G. Casella, M. Basile, M.C. Casella. Breast cancer in young women: case report and review. European Review for Medical and Pharmacological Sciences. 2006; 10: 51-52.

9. Punam Rana, Jenna Ratcliffe, Jonathan Sussman, Margaret Forbes, Mark Levine and Nicole Hodgson. Young women with breast cancer: Needs and experiences. Cogent Medicine (2017), 4: 1278836.

10. Assi HA, Khoury KE, Dbouk H, Khalil LE, Mouhieddine TH, El Saghir NS. Epidemiology and prognosis of breast cancer in young women. J Thorac Dis 2013;5( 1):S2-S8.

11. Anders CK, Hsu DS, Broadwater G, Acharya CR, Foekens JA, Zhang Y, et al. Young Age at Diagnosis Correlates With Worse Prognosis and Defines a Subset of Breast Cancers With Shared Patterns of Gene Expression. Journal of Clinical Oncology 2008;26(20):3324-30.

12. Shannon C, Smith IE. Breast cancer in adolescents and young women. Eur J Cancer 2003;39(18):2632-42.

13. Partridge. AH. IN2,Breast Cancer in Young Women: A rare disease or a significant public health problem? the breast 2014;23:s1.

14. Love RR, Duc NB, Van Dinh N, Quy TT, Xin Y, Havighurst TC. Young age as an adverse prognostic factor in premenopausal women with operable breast cancer. Clinical Breast Cancer 2002;2(4):294-8.

15. Fredholm H,Magnusson K,lindstrom SL,Garmo H,Eakar S,Lindman H et al. HM31 breast cancer in young women-age a risk factor only in those not given chemotherapy. the breast 2014;23(1):S12.

16. Gnerlich JL, Deshpande AD, Jeffe DB, Sweet A, White N, Margenthaler JA. Elevated breast cancer mortality in women younger than age 40 years compared with older women is attributed to poorer survival in early-stage disease. Journal of the American College of Surgeons 2009;208(3):341-7

17. Elkum N, Dermime S, Ajarim D,Al-Zahrani A, Alsayed A,Tulbah A,et al. Being 40 or younger is an independent risk factor for relapse in operable breast cancer patients. BMC cancer 2007; (5):222.

18. Song YJ, Shin SH, Cho JS, Park MH, Yoon JH, Jegal YJ. The role of lymphovascular invasion as a prognostic factor in patients with lymph node-positive operable invasive breast cancer. Journal of breast cancer 2011;14(3):198-203.

19. Cancello G, Maisonneuve P, Rotmensz N, Viale G, Mastropasqua MG, Pruneri G, et al. Prognosis and adjuvant treatment effects in selected breast cancer subtypes of very young women ( $<35$ years) with operable breast cancer. Ann Oncol 2010; 21(10):1974-81.

20. Alieldin NH, Abo-Elazm OM, Bilal D, Salem SE, Gouda E, Elmongy M, et al. Age at diagnosis in women with non-metastatic breast cancer: Is it related to prognosis? Journal of the Egyptian National Cancer Institute 2014;26(1):23-30.

21. Wang K RY, Li H, Zheng K, Jiang J, Zou T, et al. Comparison of Clinicopathological Features and Treatments between Young ( $\leq 40$ Years) and Older ( $>40$ Years) Female Breast Cancer Patients in West China: A Retrospective, Epidemiological, Multicenter, Case Only Study. . PloS one (2016);11(3): e0152312.

22. Kataoka A, Iwamoto T, Tokunaga E, Tomotaki A, Kumamaru H, Miyata H, et al. Young adult breast cancer patients have a poor prognosis independent of prognostic clinicopathological factors: a study from the Japanese Breast Cancer Registry. Breast Cancer Research and Treatment 2016;160(1):163-72.

23. Zhang Q, Ma B, Kang M. A retrospective comparative study of clinicopathological features between young and elderly women with breast cancer. International Journal of Clinical and Experimental Medicine 2015;8(4):586975.

24. Morrison D, Rahardja D, King E, Peng Y, Sarode V. Tumour biomarker expression relative to age and molecular subtypes of invasive breast cancer. British journal of cancer 2012;107(2):382-7.

25. Kim E-K, Noh WC, Han W, Noh D-Y. Prognostic significance of young age (< 35 years) by subtype based on ER, PR, and HER2 status in breast cancer: a nationwide registry-based study. World Journal of Surgery 2011;35(6):1244-53.

26. Celikmakas E, Karslioglu Y, Hacibey I, Kilic S, Ozturk M, Safali M, et al. HER2 positivity is high in breast cancer of young women: Experience of a single institute in Turkey. European journal of cancer 2016;61: S171.

27. Ariga R, Bloom K, Reddy VB, Kluskens L, Francescatti D, Dowlat K, et al. Fine-needle aspiration of clinically suspicious palpable breast masses with histopathologic correlation. The American Journal of Surgery 2002;184(5):410-3. 